\title{
WOMEN IN THE HOUSE OF FICTION
}




\title{
Women in the House of Fiction
}

Post-War Women Novelists

\author{
LORNA SAGE
}

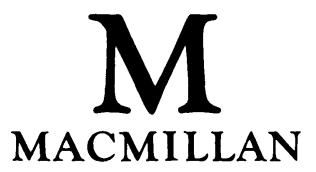


All rights reserved. No reproduction, copy or transmission of this publication may be made without written permission.

No paragraph of this publication may be reproduced, copied or transmitted save with written permission or in accordance with the provisions of the Copyright, Designs and Patents Act 1988, or under the terms of any licence permitting limited copying issued by the Copyright Licensing Agency, 90 Tottenham Court Road, London W1P 9HE.

Any person who does any unauthorised act in relation to this publication may be liable to criminal prosecution and civil claims for damages.

First published 1992 by

THE MACMILLAN PRESS LTD

Houndmills, Basingstoke, Hampshire RG21 2XS and London

Companies and representatives throughout the world

ISBN 978-0-333-28635-7 ISBN 978-1-349-22225-4 (eBook)

DOI 10.1007/978-1-349-22225-4

A catalogue record for this book is available from the British Library.

Reprinted 1994 
For my daughter Sharon 


\section{Contents}

Preface

viii

1 After the War

Simone de Beauvoir

1

Doris Lessing

Nathalie Sarraute

2 Displaced Persons 36

Christina Stead $\quad 36$

Jean Rhys 47

Elizabeth Smart $\quad 54$

Tillie Olsen $\quad 60$

Françoise Sagan $\quad 66$

3 The Middle Ground 72

Iris Murdoch $\quad 72$

Edna O'Brien $\quad 83$

Margaret Drabble $\quad 89$

Mary McCarthy $\quad 98$

4 The Movement 114

Joyce Johnson $\quad 116$

Kate Millett $\quad 122$

Erica Jong $\quad 127$

Diane Johnson $\quad 134$

Marilyn French $\quad 144$

5 Divided amongst Ourselves 153

Fay Weldon $\quad 153$

Margaret Atwood 161

Angela Carter 168

Toni Morrison $\quad 178$

Joyce Carol Oates 186

$\begin{array}{ll}\text { Notes } & 195\end{array}$

Index 214 


\section{Preface}

The first thing that caught my imagination about Simone de Beauvoir - back in my teens, back in the late 1950s - was that she lived in a hotel. This single fact seemed to imply all the rest: domesticity spurned, never cooking supper for Sartre, living on words and ideas. She was the woman writer as intellectual, for her the business of writing was public, shared and out of doors (she wrote in cafes). And the writing, of course, exposed the bad faith of living inside fictions about women's 'nature'. Not only The Second Sex, but the novels too treated the domain of character and representation as the place where the 'others' lived, playing their parts and acting out their roles - especially the female characters, who were specialists in mauvaise foi. Meanwhile the author herself had the freedom of no man's land.

My picture of Beauvoir, like everyone else's, has changed a lot since then. If she is the 'mother' of modern feminism, that's because she is a figure full of contradictions. Her characters' bad faith is nothing compared to hers. She still seems to me the right starting-point, though, because she sets up the right paradoxes in her stubborn loyalty to theory (and Sartre) in the face of her experience; in her reluctance to see herself as 'just a woman', along with her self-consciousness; in her writing of realist novels that put reality in quotation marks. This book begins with pieces on the (mostly) post-war generation of novelists who, like her, find the house of fiction ramshackle and claustrophobic. Representations fix and reproduce a world of "types" of flesh and blood human beings' (this is Nathalie Sarraute) and conspire to naturalise us in it - 'Everybody what they are. Clinging completely to themselves.' Sarraute's narrators act like domestic vampires, sucking out the spurious 'life' from their subjects:

When ... these 'live' persons, or these characters, condescend to come near me too, all I am able to do is to hover about them and try with fanatical eagerness to find the crack, the tiny crevice, the weak point as delicate as a baby's fontanelle ... . ${ }^{1}$

This sort of writing is often elevated or relegated to the territory of the avant garde, but it reads more interestingly as partisan, reactive 
de-composing. The 'character' that's really under attack is that of the traditional woman novelist.

Not that 'woman' equals 'tradition'. After all, 'the house of fiction' is a Henry James metaphor. Nonetheless, it's striking how personally women novelists make - and take - attacks on their inheritance. Their experimentalism, and their displacements, are not to be accounted for in terms of some universal state of textuality. The best brief description of that no man's land is still, I think, the one Barthes conjures out of a hat in The Pleasure of the Text:

... we are all caught up in the truth of languages, that is, in their regionality .... . For each jargon (each fiction) fights for hegemony; if power is on its side, it spreads everywhere . . . . but even out of power, even when power is against it, the rivalry is reborn, the jargons split and struggle among themselves. A ruthless topic rules the life of language; language always comes from some place, it is a warrior topos ....

The text itself is atopic, if not in its consumption at least in its production. It is not a jargon, a fiction, in it the system is overcome, undone.... . From this atopia the text catches and communicates to its reader a strange condition, at once excluded and at peace ... ${ }^{2}$

The atopic text is plural, placeless. Writing is anybody's and everybody's, the text is a heterocosm. The texts I've been reading, though, aren't like that. When they envisage a no man's land, they're consciously utopian (Sarraute, Christina Stead, Elizabeth Smart). That is, they have satiric, didactic, speculative or combative aims. They are part of the continuing war of languages. We hide this from ourselves, I think, by speaking the language of the avant garde. As Marianne DeKoven wryly points out, 'Manifestoes for avant garde ... and feminine ... stylistic practice often sound remarkably alike without knowing that they do or taking cognisance of each other in any way.' 3 This isn't a war, perhaps, but it's certainly not a peace either. Women's writing 'comes from some place'.

So 'the house of fiction' isn't, for my purposes, only a metaphor for containment. It's a reminder that fiction isn't placeless. Thinking about the novel and novel tradition this way has caused me to read realist texts rather differently. I had been planning to talk more dismissively about nostalgia. In the event I've found myself exploring - in the work of Iris Murdoch, in particular - 
a fascinating latter-day defence of what I think of as 'matriarchal realism'. Murdoch surrounds and submerges the avatars of theoretical freedom with a multitude of representations. She domesticates them, in short. And she knows just what she's doing, as her books on Sartre and Plato demonstrate. She's 'placing' metalanguages, calling into question the (seductive) power of the over-view. What she enjoys about representation (mimesis) is precisely what Plato hates - its local, partial, illusionist tricks; everything that makes the quotidian world of passion, habit, conflict and muddle seem 'real'. Quantity is a factor here too, the burgeoning detail, huge cast-lists, and so much otherness that dualism looks defeated. Murdoch has a good phrase - 'a great hall of reflection' - for what Plato thought of as the 'cave'. It's not a bad description of her kind of novel. She also helps to explain the continuing importance of the novel's mirroring function, which is by no means confined to realism.

There's been a revaluation of representation since the iconoclastic heyday of the 'new novel'. Angela Carter's The Infernal Desire Machines of Doctor Hoffman suggests why: reflections don't only reproduce, they breed new meanings, and multiply possibilities -

The Minister sent the Determination Police round to break all the mirrors because of the lawless images they were disseminating. Since mirrors offer alternatives, the mirrors had all turned into fissures or crannies in the hitherto hard-edged world of here and now .... 4

The women's movement, and feminist politics, have found fictional shape in narratives that explore self-division, the multiplicity of ways to be. The novelists, I want to argue, are agents of alterneity, interested - after all - in reinscribing the boundaries of fiction. They construct halls of reflection, and they take self-consciousness for granted, as one strategy amongst many. What this book tries to do is to characterise and celebrate what they've built. Of course, there's an orgy of demolition going on as well. But the novel has proved a lot more habitable than it looked to Beauvoir: uncovering its conventions has disclosed its power to define an invented place. Which is perhaps just another way of pointing to the utopian uses women have found for fiction. I've tried not to travesty the achievements of these writers by reducing them to sameness; or by making them all symbolise some amorphous 'difference' (hence my allergy to 'atopia'). There's no one way of placing the woman novelist - 
or even of displacing her. The language of domesticity hasn't died, at all. It flourishes alongside street-wise, picaresque writing that embraces mobility and change. I know, given my old picture of Beauvoir, which I'm programmed to prefer. However, they do have this in common: they pour back into the novel conviction, mockery and partisan passion. 